\title{
Winescape's Aesthetic Impact on Lodging Room Prices: A Spatial Analysis of the Douro Region
}

\author{
Alexandre Guedes (iD) and João Rebelo (it) \\ Department of Economics, Sociology and Management, University of Trás-os-Montes and Alto Douro, Vila \\ Real, Portugal
}

\begin{abstract}
This study estimates the local economic effects on lodging establishments' room prices of the winescape's aesthetic attributes, mostly shaped by the wine filiere, combined with other fundamental situation, site-specific and online reputation factors. A semi-parametric geographically weighted regression model was applied to examine how lodging establishments' room prices vary in space. The hedonic pricing model was based on Booking.com's room rates of lodging establishments located in the Douro region in Portugal, a monocultural environment, which is predominantly rural and dominated by vineyards, combining small towns with a hybrid urban-rural character. The results suggest that landscape factors, which encapsulate structural features of the Douro wine region, exert a statistically significant effect on lodging establishments' room prices.
\end{abstract}

\section{KEYWORDS}

Winescape; lodging room price; hedonic pricing method; geographically weighted regression; Douro

\section{Introduction}

Tourism is largely driven by space insomuch as tourism's economy is explained by the concept of utility of places, which determines people to migrate as customers. Unlike other consumer goods/services, tourism's supply is not relocatable or displaceable (Miossec, 1977). Production and consumption are synchronized and coextensive. Therefore, location can be a key determinant of product differentiation, equally in terms of its production and consumption (Bull, 1998).

Rural spaces and specifically wine regions' landscapes are clearly an illustration where the location is an intrinsic characteristic that outlines product differentiation based on inherent physical qualities (Bruwer, 2003). These endemic factors define the character and "difference of place" (Bruwer, 2003, p. 424) as a key influential cause of attraction and appeal to visitors (Getz \& Brown, 2006). These unique set of physical, cultural and natural environments have been coined as "touristic terroir" (Hall \& Mitchell, 2002) and winescape (Hall, Sharples, Cambourne, \& Macionis, 2000; Peters, 1997; Telfer, 2000), which are impregnated of specific physical, social and cultural qualities (Hall et al., 2000) that define the expression of the wine region's scenic beauty (Bruwer \& Alant, 2009) and aesthetic value. 
Landscape and nature-related attributes, "i.e. scenery and/or natural settings" (Bruwer, Gross, \& Lee, 2016, p. 183) alongside with the rural landscape's quality (Carmichael, 2005) exert an influential pull effect on tourism's demand (Santeramo, Seccia, \& Nardone, 2017), and are amongst the foremost destination attributes motivating visitors who "seek hedonic experiences within the context of the region's winescape" (Bruwer et al., 2016, p. 182).

Therefore, space and location are clear determinants of tourism's development and, particularly, of lodging establishments that are mostly susceptible to location and regional context stimuli, which exerts strong influence on demand (Yang \& Cai, 2016), competitiveness/performance (Molina-Azorin, Pereira-Moliner, \& Claver-Cortés's, 2010) and room rates (Bull, 1994; Peña, Jamilena, Molina, \& Olmo, 2015).

One method that is appropriate to measure the location and environmental effects on the economic value of lodging establishments is the hedonic pricing model (Fleischer, 2012; Santeramo \& Barbieri, 2017), which derives implicit attribute prices under an equilibrium market. Hedonic analysis has substantiated many of the outcomes of numerous environmental and landscape conditions on the lodging establishments' room prices (Andersson \& Hoffmann, 2008; Hamilton, 2007; Hunt, Boxall, Englin, \& Haider, 2005; Nelson, 2010; Peña et al., 2015) but scant attention has been given to the effects of location on lodging establishments' room prices in wine regions, considered a monocultural environment (Poitras \& Getz, 2006; Viers et al., 2013), despite some contribution to measure the influence of environmental attributes on rural tourism rental and room prices (Bilbao-Terol, Cañal-Fernández, Valdés, \& Del Valle, 2017; Peña et al., 2015; Suárez-Vega, Santana Jiménez, \& Hernández Guerra, 2009). Also, most of the hedonic pricing models in the hospitality sector have been applied to urban morphologies and sea resorts (Bull, 1994; Latinopoulos, 2018; Thrane, 2007; Zhang, Zhang, Lu, Cheng, \& Zhang, 2011), characterized by spatial proximity and heterogeneity, which explained lodging's room prices significant spatial autocorrelation.

Winescapes tend to combine specific environmental and landscape amenities (e.g. vineyards and wineries) within a regional and low-density context, unlike urban and sea resorts. Thus, in such an environment, can one expect room prices to be spatially dependent? Equally, do winescape's environmental features exert a significant impact on lodging establishments' room prices, i.e. do room prices have a positive spatial dependence on environmental factors?

Therefore, the aim of this research is to estimate the local economic effects on lodging's room prices of the winescape's environmental/landscape attributes, mostly shaped by the wine filière, combined with fundamental situation (e.g. accessibility), site-specific and online reputation factors. To analyze the wine region's winescape spatial economic effect on lodging room prices, a hedonic pricing model is applied. Explicitly, a geographically weighted regression method is used as an exploratory tool, that enables to model strategic individual local interactions and allows a post-structuralist interpretation that looks "(...) closely at spatially-situated interactions (...)" (Murdoch, 2006, pp. 2-3).

To achieve the goal of this research, we observed the Portuguese Douro region, a monocultural environment which has been regulated for more than 200 years by its core traditional productive activity, the wine filiere, combined with structural landscape features imbued with high aesthetic and cultural value. Additionally, the Douro region is positioning itself as a tourist destination (Rebelo, Guedes, Gomes, \& Sequeira, 2013) 
based on its winescape's distinctiveness, perceived as a destination image (Bruwer \& Gross, 2017; Bruwer \& Joy, 2017; Byrd, Canziani, Hsieh, Debbage, \& Sönmez, 2016), which makes it an excellent showcase of a winescape environment.

We believe that this study contributes to gain a deeper understanding of the demand for agritourism and particularly for wine tourism, since it includes a spatial econometric model using geographical information systems (GIS) in order to explore the impact on lodging room prices of specific spatial varying attributes that are encapsulated within the winescape's framework. Moreover, according to our knowledge, this is the first application of a spatial hedonic pricing method to lodging establishments located in a winescape setting with a low-density and monocultural environment.

\section{Literature review}

\section{Hedonic pricing}

Santeramo and Barbieri (2017) offer a comprehensive outline of the methodologies and practice used in research to assess the demand of agritourism which are classified into two main categories: Stated and Revealed preference methods. The hedonic price method (hedonic regression) falls within the scope of consumer revealed preference approach which focuses on price response by using a price-attribute function to estimate the joint effect of attributes on marginal implicit prices and determine the implicit demand. Based on the concept of hedonic utility presented by Lancaster (1966), Rosen (1974) developed the theory of hedonic pricing which hypothesized that goods can be "valued for their utility-bearing attributes and characteristics" and proposed a hedonic model based on econometric estimation of implicit prices that "guides both consumer and producer locational decisions in characteristics space" (Rosen, 1974, p. 34).

Since Rosen (1974) the hedonic pricing has been widely used to estimate the price of housing and describe price variations contingent on locational and property attributes (Bull, 1998). This method has also been applied to tourism by modeling room price based on the combination of two main groups of attributes: "market-induced" which tend to be variable characteristics and "non-market" factors (Fleischer, 2012, p. 599).

Within the market-induced attributes, research has acknowledged key site features that are correlated with lodging establishments' characteristics, namely star rating (Espinet, Saez, Coenders, \& Fluvià, 2003; Israeli, 2002), online reputation (Yacouel \& Fleischer, 2012), size (Espinet et al., 2003), age (Hung, Shang, \& Wang, 2010), affiliation with a brand name (Wu, 1999), hotel-chain membership (White \& Mulligan, 2002) as well as internal facilities (Latinopoulos, 2018; Monty \& Skidmore, 2003).

Also, research has identified a string of "non-market" (Fleischer, 2012, p. 599) attributes as key predictors of room prices. These have concentrated on two main dimensions: (1) the distance from external features, namely from city centers (Thrane, 2007; Zhang et al., 2011), neighborhoods (Carvell \& Herrin, 1990), environmental and landscape features (Bull, 1998; Hunt et al., 2005; Peña et al., 2015) and accessibility factors (Bull, 1994; Zhang et al., 2011); (2) and the landscape aesthetic value recorded by Bull (1998, p. 145) as the "extent of a view" which consists of a spectrum of "neighborhood amenities" (Latinopoulos, 2018, p. 88), that define the setting's quality and accordingly its effect on the room's value dependent on changing factors such as the view from a room (Fleischer, 2012; Latinopoulos, 2018), and the type and quality of a landscape (Hamilton, 2007; 
Hunt et al., 2005). Furthermore, room rates tend to be influenced by neighboring lodging establishments (Abrate, Fraquelli, \& Viglia, 2012), and thus abide by a distance decay effect. To capture the "distance-decay" effect of spatially heterogeneous processes, such as spatially varying room prices in response to "non-market" attributes, recent studies (e.g. Latinopoulos, 2018; Soler \& Gemar, 2018; Zhang et al., 2011) have applied geographically weighted regression (GWR) method, which expands the Ordinary Linear Regression (OLS) model, commonly used to estimate hedonic price models.

In the case of lodging establishments located in rural and low-density settings various studies have analyzed the effects of the environmental context on rural tourism (Nakaya, 2015; Suárez-Vega et al., 2009) as well as the correlation between rural tourism and agricultural amenities (Bilbao-Terol et al., 2017; Fleischer \& Tchetchick, 2005; Le Goffe, 2000; Vanslembrouck, Van Huylenbroek, \& Van Mennesel, 2005).

Likewise, in the particular circumstance of wine tourism specific implications outlined within the winescape's construct have captured the importance of aesthetic elements (Williams, 2001) in the wine tourist's experience that are prompted by the wine region's natural environment (Bruwer \& Lesschaeve, 2012).

\section{Winescape concept}

The concept of winescape has since its introduction by Peters (1997) expanded the original wine region's meaning, based on wine production processes, by adding an aesthetic and experiential utility function, which stems from the wine region's natural setting and landscape imagery (Williams, 2001). This concept has, thus, evolved to provide a "framework for scenic interpretation" of the wine region (Bruwer \& Gross, 2017, p. 499) and express the wine tourism's destination image (Bruwer \& Joy, 2017). This means that the tourism experience is embedded into the wine regional setting (i.e. natural environment) which therefore acts as an important factor of consumption of wine tourism (Bruwer et al., 2016). According to Bruwer and Lesschaeve (2012), the winescape provides a good illustration where the natural environment, i.e. the "region's natural beauty/setting (landscape)" (p. 611), is the most important dimension noted by visitors.

Several publications have given attention to the winescape's conceptualization, particularly to establish the key attributes of the wine tourism experience. In doing so, research has followed two approaches that focus on the place where the wine tourism experience ensues: a micro approach and a macro approach (Bruwer \& Gross, 2017; Bruwer \& Joy, 2017). The micro approach, which is advocated by Quintal, Thomas, and Phau (2015), looks at the winescape "as the environment at a specific winery" (p. 597), viewing it (the winescape) as a circumstantial element which affects the wine tourism experience in an identified environment (the winery). Conversely, the macro approach looks at the winescape as the wine region, by observing all attributes which condense the destination wine region in order to predict wine tourist consumption behavior (Bruwer \& Gross, 2017).

Despite the clear methodological divergence between both approaches, research outputs have unanimously exhibited the importance of the "natural landscape" (Quintal et al., 2015, p. 602) or "nature-related dimension (i.e. scenery and/or natural settings)" (Bruwer et al., 2016, p. 183) as a critical dimension of the winescape which is perceived by tourists. These findings suggest the vital importance of the spatial variable dimension that captures regional/local variations on tourists' preferences influenced by the 
winescape's aesthetic and landscape value, which GWR can model by depicting different relationships that exist at different points in space (Brunsdon, Fotheringham, \& Charlton, 1996; Nakaya, 2015).

Thus, the combination of both approaches (micro and macro) by capturing local changing effects on lodging room prices in response to variable conditions of the winescape's attributes and integrating it into a holistic view of the wine region destination fits the purpose of this research which applies a spatial hedonic price model within a regional context.

\section{Methodology}

\section{Study area}

The Douro region is located in the north eastern part of mainland Portugal. Its landscape is predominantly rural $(97 \%)(I N E, 2016)$ and mostly dominated by vineyards which define the Demarcated Douro Region (DDR) - considered one of the oldest demarcated and regulated wine regions in the world (established in 1756) where the renowned Port wine is produced (Caldas \& Rebelo, 2013). This region is bisected horizontally by the Douro river, a critical natural element that shapes this region's landscape and its aesthetic value, currently considered a vital river cruise hot spot (Gouveia, Rebelo, Lourenço-Gomes, \& Guedes, 2017; Guedes \& Joukes, 2016).

Within the DDR, lies the Alto Douro Wine Region (ADWR), (10\% of the DDR) classified World Heritage Site by the United Nations Educational, Scientific and Cultural Organization (UNESCO) in 2001, which distinguished this region's cultural and landscape uniqueness.

\section{Data}

A total of 130 lodging establishments located in the Douro region were extracted from a database provided by the regional destination management organization (DMO) responsible for promoting the Porto and North of Portugal destination, which is consistent with the total number of accommodation establishments reported by Statistics Portugal (INE, 2016). The obtained list contains small-medium scale accommodation units. $79 \%$ of lodging establishments have, on average, seven rooms per unit and are classified as rural tourism and Alojamento Local (hostel) according to the Portuguese legal framework. The remainder (21\%) are small-medium size hotels with an average of 37 rooms per accommodation unit (Table 1).

Room prices were collected from Booking.com, one of the largest online travel metasearch engines, ranked first as compared to all other sites in its main category, i.e. Accommodation and Hotels, by Similarweb (2018), which renders it a relevant online reputation

Table 1. Data—lodging establishments' categories and average size.

\begin{tabular}{lcc}
\hline Lodging establishment's categories & $\begin{array}{c}\text { Number of units } \\
\text { [abs. (rel.)] }\end{array}$ & $\begin{array}{c}\text { Average number of rooms } \\
\text { [average; std. dev.] }\end{array}$ \\
\hline Alojamento local (hostels) & $48(37 \%)$ & $6.6 ; 8.6$ \\
TER/TH (rural tourism) & $55(42 \%)$ & $7.2 ; 3.2$ \\
Hotels & $27(21 \%)$ & $37.0 ; 33.9$ \\
Total & $130(100 \%)$ & $13.2 ; 20.3$ \\
\hline
\end{tabular}


measure that is based on the consumer's post-experience review as well as a representative source that provides an echo of the price that consumers are willing to pay (Chen \& Rothschild, 2010). This allows to control for company bias. Likewise, it can be considered an appropriate track of the "(...) vendor's perception of the implicit price for the hotel's product" (Chen \& Rothschild, 2010, p. 3).

Room prices were extracted from January to December 2016. Since the Booking.com's rates can vary over time according to room availability, special offers, discounts, etc., in order to control for these factors, we recorded the highest rate for an overnight stay in a double room for each accommodation unit on the nearest Saturday of the 15th of each month and an annual average room price was calculated per lodging establishment. This methodology was chosen to capture room rates subject to the same demand conditions and thus mitigate the deviational effect of seasonality in the study, which followed a comparable methodology of previous studies that applied the hedonic pricing method to lodging room prices (Fleischer, 2012; Latinopoulos, 2018).

\section{Exogenous attributes: a multivariate analysis}

Based on the literature review as well as on the study area's geographical features, nine exogenous attributes were derived (Table 2) which capture the aesthetic, location, sitespecific and online reputation room price controlling attributes.

Drawing on the diversity of accommodation typologies due to our study's lowdensity geography we considered two exogenous site-specific attributes which we deem to mirror relevant accommodation units' physical and organizational traits (Andersson, 2010): (a) number of rooms; and (b) types of lodging. Despite being referred by numerous authors as a key influential exogenous attribute affecting room prices (Israeli, 2002; Zhang et al., 2011), star-rating system was not included in our model due to our sample's heterogenous nature, predominantly comprised by small and medium-size accommodation units which is an outcome of the study's geographical context.

Table 2. Exogenous attributes.

\begin{tabular}{|c|c|c|c|}
\hline \multicolumn{4}{|c|}{ Exogenous attributes } \\
\hline Types of attributes & Acronyms & Short description & Units \\
\hline \multicolumn{4}{|l|}{ Non-market } \\
\hline \multirow[t]{6}{*}{ Situation } & DR-distance & $\begin{array}{l}\text { Minimum distance between a tourist accommodation unit and the } \\
\text { Douro River }\end{array}$ & Distance (m) \\
\hline & V-distance & $\begin{array}{l}\text { Minimum distance between a tourist accommodation unit and a } \\
\text { vineyard }\end{array}$ & Distance $(\mathrm{m})$ \\
\hline & ADV-distance & $\begin{array}{l}\text { Minimum distance between a tourist accommodation unit and the } \\
\text { Alto Douro Wine Region-UNESCO }\end{array}$ & Distance $(\mathrm{m})$ \\
\hline & Q-distance & $\begin{array}{l}\text { Minimum distance between a tourist accommodation unit and its } \\
\text { nearest quinta }\end{array}$ & Distance $(\mathrm{m})$ \\
\hline & TS-distance & $\begin{array}{l}\text { Minimum distance between a tourist accommodation unit and its } \\
\text { nearest train station }\end{array}$ & Distance $(\mathrm{m})$ \\
\hline & MR-distance & $\begin{array}{l}\text { Minimum distance between a tourist accommodation unit and its } \\
\text { nearest main road }\end{array}$ & Distance (m) \\
\hline \multicolumn{4}{|l|}{ Market-induced } \\
\hline \multirow[t]{2}{*}{ Site-specific } & $\mathrm{R}$ & Number of rooms & $\begin{array}{l}\text { Number of } \\
\text { rooms }\end{array}$ \\
\hline & TA & Types of accommodation & $1 ; 2 ; 3$ \\
\hline Online reputation & $\mathrm{BR}$ & Booking.com rate & {$[2.5-10]$} \\
\hline
\end{tabular}


A relevant dimension that affects room prices is comprised by a set of location characteristics that were measured considering the shortest straight linear distance to each accommodation unit (Figure 1). QGIS (version 2.14.19-Essen; Free Software Foundation, Inc, 2017), a geographic information system (GIS) software, was used to measure and store linear distances between accommodation units and situation factors.

Nine exogenous variables were built-in our model based on their contextual implications and distinctive value both in terms of rural setting and as critical pull factors for the success and development of the Douro as a tourist destination (Rebelo et al., 2013). The Douro river is a signifyingly landscape feature that gave its name to the region and accrues economic, historical, environmental, and aesthetical value. Vineyards were also considered an essential element that distinguishes the landscape's rural quality and attraction. The ADWR stripe was regarded a key independent variable due to its UNESCO significance as well as being viewed as the most preserved wine landscape segment of the DDR. The quintas were also chosen as an influential variable due to their impact on the landscape's organization (Rebelo et al., 2013) and both on the rural and tourism economies. Two train stations in the study area were selected, considering the significance of railway as an accessibility factor that links the Douro to Oporto, where the second most important Portuguese international airport is located as well as their hypothetical function as internal hubs. Dispersion is also a characteristic of low-density areas which challenges accessibility within the region, being road availability (Donnges, 2003) one factor that can affect tourism development and therefore room prices. Thus, the nearest distance of each accommodation unit to the Douro's main road network was considered as a situation attribute. Finally, Booking.com scoring system was used as an online reputation factor which has been identified on previous research as an essential contemporary exogenous attribute that can influence room price (Li, Ghose, \& Ipeirotis, 2008; Yacouel \& Fleischer, 2012).

Following the preceding recognition of typologies of price explanatory variables, we further advanced the model's explanatory construct by exploring the underlying factor structure (latent variables) of our nine variables using exploratory factor analysis (EFA). This is particularly relevant due to seemingly underlying constructs influenced by the

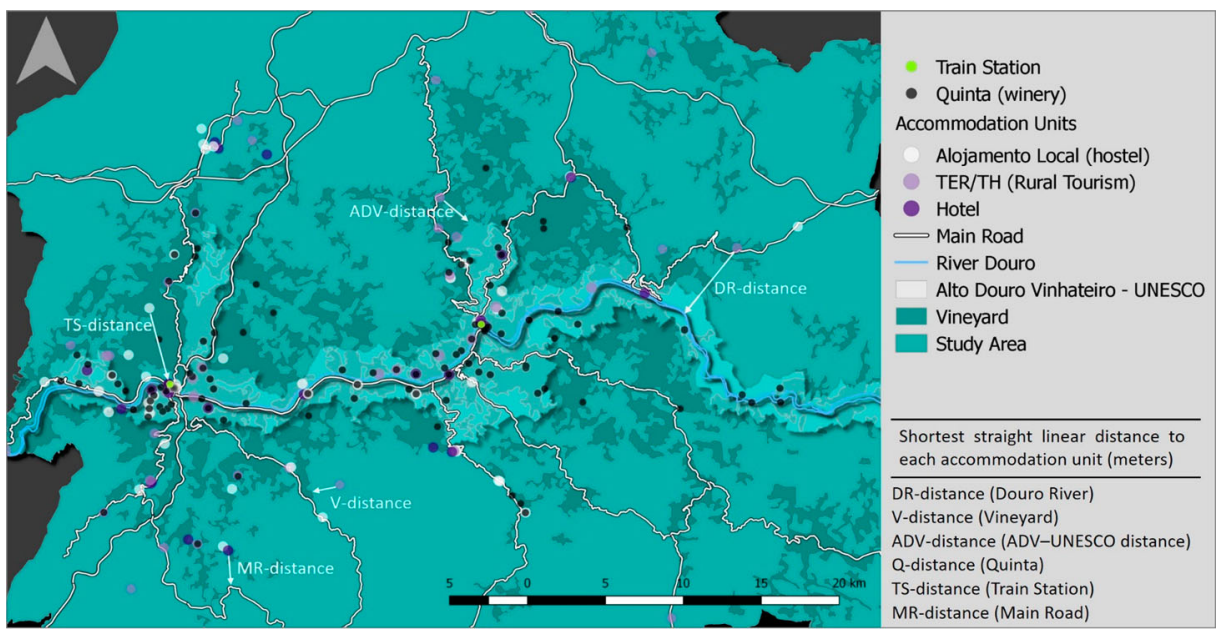

Figure 1. Location characteristics. 
groups of exogenous attributes which we mentioned before classified as: (1) marketinduced; and (2) non-market.

Prior to this interpretation we used a natural log transformation of our original continuous variables to moderate skewed distributions (Wooldridge, 2009). For "Booking ratings" we chose to normalize due to it being a final score resulting from an average calculated by Booking.com based on six features assigned by the reviewer (Costantino, Martinelli, \& Petrocchi, 2012; Mellinas, María-Dolores, \& García, 2016). Furthermore, "Type of Accommodation", being an exogenous categorical variable was kept in its original format.

To submit our variables to EFA the sample size should be larger than 100 and "(...) have at least five times as many observations as the number of variables to be analyzed (...)" (Hair, Black, Babin, \& Anderson, 2014, p. 101). Due to our nine variables, a minimum threshold of 45 observations was required, which we met $(n=130)$. High intercorrelations were checked by examining an $R$-matrix, a correlation matrix. The presence of clusters was uncovered due to relevant correlation coefficients ( $>0.3$ and less than 0.8 ) (Table 3 ) between subsets of variables which implies underlying dimensions that are being measured by our set of exogenous variables. Both the Bartlett test of sphericity (501.71 at $p=.000)$ and the Kaiser-Meyer-Olkin measure of sampling adequacy (KMO $=.68$ ) indicated a significant level of correlation between variables to perform a factor analysis. Furthermore, the determinant of the $R$-matrix was greater than $0.00001(0.018)$, indicating that multicollinearity was not an issue.

To extract factors, we applied the Principle Component method with Varimax rotation and assumed Kaiser's criterion to retain only factors with eigenvalues greater than 1 (latent root) (Hair et al., 2014). A scree plot was used to verify and determine the number of factors extracted. The preliminary analysis exhibited a three-factor result, accounting for $72 \%$ of the variance. The variable "Booking ratings" (Norm_BR) reported a low communality value which indicated a small proportion of variance explained by the extracted factors. Consequently, this item was removed, and the analysis was repeated. Again, a threefactor solution was retained after "Booking ratings" was excluded, but their explanatory ability improved by six percentage points accounting for $78 \%$ of total variance.

Variables "Douro River", "Vineyard", "Alto Douro Wine Region-UNESCO" and "Quinta" all loaded highly (>0.707) on factor 1 (Table 4) which was designated "Landscape Factor", due to their latent common attribute which distinctively springs from the Douro's environmental context. This factor accounted for $40 \%$ of the variance. The second factor, which explained almost $22 \%$ of total variance, is likewise a situation feature that sanctions an underlying

Table 3. R-matrix.

\begin{tabular}{|c|c|c|c|c|c|c|c|c|}
\hline \multicolumn{3}{|c|}{ Correlation matrix ${ }^{a}$} & \multirow[b]{2}{*}{ LnV } & \multirow[b]{2}{*}{ LnADV } & \multirow[b]{2}{*}{$\operatorname{LnQ}$} & \multirow[b]{2}{*}{ LnMR } & \multirow[b]{2}{*}{ LnTS } & \multirow[b]{2}{*}{ Norm_BR } \\
\hline $\operatorname{LnR}$ & TA & LnDR & & & & & & \\
\hline 1.00 & $\begin{array}{l}\mathbf{0 . 6 7} \\
1.00\end{array}$ & $\begin{array}{r}-0.04 \\
-0.08 \\
1.00\end{array}$ & $\begin{array}{l}0.06 \\
0.01 \\
\mathbf{0 . 4 0} \\
1.00\end{array}$ & $\begin{array}{r}-0.04 \\
-0.11 \\
\mathbf{0 . 7 9} \\
\mathbf{0 . 5 4} \\
1.00\end{array}$ & $\begin{array}{r}0.05 \\
-0.03 \\
\mathbf{0 . 4 2} \\
\mathbf{0 . 5 2} \\
\mathbf{0 . 5 6} \\
1.00\end{array}$ & $\begin{array}{r}-0.11 \\
-0.09 \\
0.26 \\
-0.16 \\
0.16 \\
0.03 \\
1.00\end{array}$ & $\begin{array}{r}-0.13 \\
-0.11 \\
\mathbf{0 . 6 4} \\
0.32 \\
\mathbf{0 . 6 3} \\
0.35 \\
\mathbf{0 . 6 2} \\
1.00\end{array}$ & $\begin{array}{r}-0.30 \\
-0.11 \\
-0.05 \\
-0.21 \\
-0.05 \\
-0.10 \\
0.19 \\
0.10 \\
1.00\end{array}$ \\
\hline
\end{tabular}

a Determinant: $0.018(>0.00001)$. 
Table 4. Results of exploratory factor analysis—rotated factor loadings, eigenvalue and percentage of variance.

\begin{tabular}{lccr}
\hline & \multicolumn{3}{c}{ Factors (component) } \\
\cline { 2 - 4 } Variables & $F 1$ & $F 2$ & $F 3$ \\
Number of rooms (LnR) & Landscape factor & Accessibility factor & Site factor \\
Type of accommodation (TA) & 0.041 & -0.077 & $\mathbf{0 . 9 0 9}$ \\
Douro River (LnDR) & -0.049 & -0.029 & $\mathbf{0 . 9 1 3}$ \\
Vinyards (LnV) & $\mathbf{0 . 7 0 7}$ & 0.473 & -0.035 \\
Alto Douro Vinhateiro-UNESCO (LnADV) & $\mathbf{0 . 8 2 8}$ & -0.17 & 0.038 \\
Quintas (LnQ) & $\mathbf{0 . 8 4 2}$ & 0.336 & -0.065 \\
Main roads (LnMR) & $\mathbf{0 . 7 7 6}$ & 0.02 & 0.018 \\
Train stations (LnTS) & -0.116 & $\mathbf{0 . 9 2 2}$ & -0.052 \\
Extraction method: principal component analysis. rotation method: varimax with kaiser normalization & -0.088 \\
Eigenvalue & 0.207 & 1.75 & 1.307 \\
\% Variance & 40.087 & 21.877 & 16.331 \\
\hline
\end{tabular}

dimension which is associated with accessibility. This is clearly displayed by both variables which load highly (>0.786) on this factor, i.e. "Main Roads" and "Train Stations". The third extracted factor, which we labeled "Site Factor", accounted for $16 \%$ of the variance. This factor is an evident representation of site attributes, due to the extremely high loadings $(>0.9)$ of both "Number of Rooms" and "Type of Accommodation" variables.

Thus, EFA allowed to estimate latent variables (factors) by summarizing and reducing (Hair et al., 2014) our initial set of exogenous variables that we defined and captured based on preceding literature review (Figure 2), which we believe yields a strategic model outline for further OLS and GWR analysis.

\section{Regression specification}

Based on the previous data reduction, the annual average room price $\left(P_{i}\right)$ of lodging establishments was modeled (hedonic pricing) as a function of the resultant factors, i.e. landscape $\left(F 1_{i}\right)$, accessibility $\left(F 2_{i}\right)$, site $\left(F 3_{i}\right)$, and online reputation $\left(B R_{i}\right)$ factors:

$$
P_{i}=f_{i}\left(F 1_{i, k}, F 2_{i, n}, F 3_{i, m}, B R_{i, t}\right)
$$

Considering $K_{j}$ to be the whole set of lodging establishments' factors $\left(F 1_{k}, F 2_{n}, F 3_{m}\right.$ and $\left.B R_{t}\right)$, the empirical demonstration of the $i$-th lodging establishment's annual average room price is represented as

$$
P_{i}=\alpha+\boldsymbol{\beta} K_{i, j}+\varepsilon_{i}
$$

where $P_{i}$ is the implicit annual average room price regarding $K_{j}$ attributes, $\alpha$ is the intercept term, $\beta$ is the vector of $K_{j}$ coefficients, $K$ are the $j$ attributes of the lodging establishment and $\varepsilon$ is a stochastic residual term.

To choose the appropriate hedonic price model's specification we estimated two models based on OLS approach: (1) one which assumes the room price in its linear form $\left(P_{i}\right)$; and (2) another which applies a natural logarithmic transformation to the room price $\left(L n P_{i}\right)$. Both model specifications capture the dependent variable's response to our models' explanatory variables ( $F$ values respectively equal to 17.197 and 18.348 ). Given that the second hedonic price model construct provides the best fitting coefficients $\left(F=18.348, R^{2}=0.37\right)$, it was chosen as the most suitable to determine the association amongst the room price and the set of explanatory variables. 


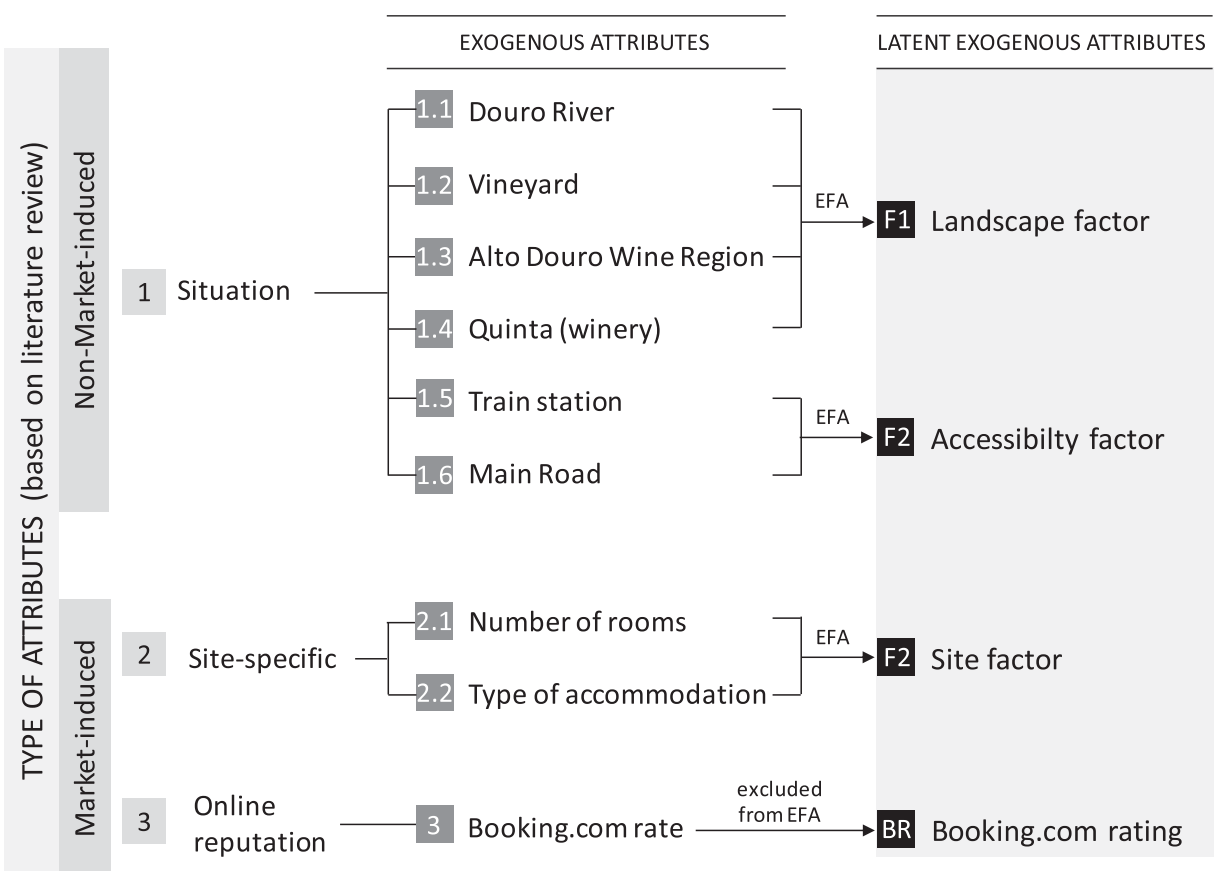

Figure 2. Data summarization.

The partial derivative of the utility function with respect to a lodging establishment's attribute $\left(K_{j}\right)$ is the consumer's marginal willingness to pay function for that attribute, as follows:

$$
\frac{\partial P_{i}}{\partial K_{i j}}=\frac{\partial P\left(K_{j}\right)}{\partial K_{i j}}
$$

In the OLS regression approach the marginal price effect with respect to a lodging establishment's attribute $\left(K_{j}\right)$ is assumed to be fixed and thus the estimated coefficients are expected to be universal (Brunsdon et al., 1996). However, in our case it is sensible to suppose that, namely landscape traits and accessibility attributes are local variable factors "rather than a global utility assumed for each commodity" (Brunsdon et al., 1996, p. 283), which presupposes spatial variation of the estimated coefficients.

One of the proposed statistical methods that enables the model's coefficients for each location in space to be estimated and mapped is that of geographically weighted regression (GWR). GWR expands the standard linear regression model by combining spatial data and enabling local variations of the model's coefficient estimates which are therefore specific to a location $i$, with geographic coordinates $\left(x_{i}, y_{i}\right)$ (Brunsdon et al., 1996), where $x$ stands for longitude and $y$ for latitude.

Consequently, the $i$-th lodging establishment's annual average room price at each location $\left(x_{i}, y_{i}\right)$ is represented as

$$
P_{i}\left(x_{i}, y_{i}\right)=\alpha\left(x_{i}, y_{i}\right)+\sum_{j=1}^{q} \beta_{j}\left(x_{i}, y_{i}\right) K_{i, j}+\varepsilon_{i}
$$


Function $P_{i}\left(x_{i}, y_{i}\right)$ describes a local correlation over location $\left(x_{i}, y_{i}\right)$ where $\alpha\left(x_{i}, y_{i}\right)$ and $\beta_{j}\left(x_{i}, y_{i}\right)$ are exclusive to that place in space. Despite the previous model being based on the conjecture that the function $P_{i}\left(x_{i}, y_{i}\right)$ explains a local correlation over location $\left(x_{i}, y_{i}\right)$, which entails that all coefficients vary across space (geographically varying), in specific circumstances regression coefficients may be fixed which means they have a global impact on room prices. Thus, to allow the presence in our model of both globally fixed and geographically varying coefficients a semi-parametric GWR model is applied, as follows:

$$
P_{i}\left(x_{i}, y_{i}\right)=\alpha\left(x_{i}, y_{i}\right)+\sum_{j=1}^{r} \beta_{j} K_{i, j}+\sum_{j=r+1}^{q} \beta_{j}\left(x_{i}, y_{i}\right) K_{i, j}+\varepsilon_{i}
$$

The GWR model's performance requires prior calibration which assumes that the observed data near to location $i$ with coordinates $\left(x_{i}, y_{i}\right)$ has greater influence in the estimation of the $\beta_{j}\left(x_{i}, y_{i}\right)$ 's than observations located further from $i$. Thus, an observation is weighted based on its distance to point $i$ so that the weighting of an observation in location $p$ varies with $i$ (Charlton \& Fotheringham, 2009). Also, due to the dispersed configuration of our data (Figure 1), which could determine that less data points are influencing the estimation of local regressors, an adaptive bi-square spatial kernel function was applied which yields spatially adaptive kernels, i.e. it applies small bandwidths in spaces where the data points are more concentrated and larger bandwidths where the data points are more dispersed. Thus, weights were calculated according to the following weighting function $\left(w_{i, p}\right)$ :

$$
\text { wi, } p= \begin{cases}\left(1-\left(d_{i, p} / \theta_{i(k)}\right)^{2}\right)^{2}, & d_{i, p}<\theta_{i(k)} \\ 0, & d_{i, p}>\theta_{i() k}\end{cases}
$$

where $w_{i, p}$ is the weight of an observation at location $p$ to estimate the coefficient at point $i, d_{i}$ $p$ is the Euclidean distance between $i$ and $p$; and $\theta_{i(k)}$ is an adaptive bandwidth size defined as the $k$-th nearest neighbor distance.

Our weighting function is susceptible to the level of distance-decay and consequently the ideal kernel bandwidth is a compromise between bias and variance (Nakaya, 2015), which can be determined by reducing the corrected Akaike Information Criterion (AICC) for a particular $\theta_{i}$ (Fotheringham, Brunsdon, \& Charlton, 2002).

To run our econometric model, we used GWR 4.09, a Geographically Weighted Regression Modelling software written by Nakaya, Fotheringham, Charlton, and Brunsdon (2009). This software also includes a fitting routine ( $L$ to $G$; local to global variable selection) for automated variable selection which runs a sequence of model evaluations to uncover local and fixed globally explanatory effects on the dependent variable (Nakaya et al., 2009).

After running GWR 4.09 the optimal fitting combination of terms is defined by three local (F1, F2 and F3) and one global (BR) exogenous variables. As a result, the GWR semiparametric model, an extension of GWR which combines globally fixed and geographically varying coefficients, can be specified as follows:

$$
\begin{aligned}
& \operatorname{Ln} P_{i}\left(x_{i}, y_{i}\right)=\alpha\left(x_{i}, y_{i}\right)+\sum_{j=r+1}^{q} \beta_{i}\left(x_{i}, y_{i}\right) F 1_{i, j}++\sum_{j=r+1}^{q} \beta_{i}\left(x_{i}, y_{i}\right) F 2_{i, j} \\
& ++\sum_{j=r+1}^{q} \beta_{i}\left(x_{i}, y_{i}\right) F 3_{i, j}+\sum_{j=1}^{r} \beta_{i} B R_{i, j}+\varepsilon_{i}
\end{aligned}
$$


In addition, GWR results were mapped to identify and construe patterns and relationships. Specifically, $R^{2}$ measures of goodness-of-fit, parameter estimates, and $t$-test values were spatially interpolated using Inverse Distance Weighted (IDW) interpolation.

\section{Results}

Given that our model's factors are latent variables based on logarithms, it is important to take notice of their significance and estimated coefficients' signs. The OLS results (Table 5) display a significant impact of all factors on the lodging establishment's annual average room price $\left(P_{i}\right)$. The estimated coefficients' signs concur with the theoretical assumption previously debated, namely that the increase of distance of lodging establishments from landscape and accessibility factors has a negative impact on room prices. Likewise, site factors' results conform according to the literature review (Zhang et al., 2011), i.e. a more sophisticated service which in our case is represented by the hotel as opposed to hostels (Alojamento Local) as well as the size of lodging establishments have a positive effect on room prices. Furthermore, Booking.com rating coefficient (global attribute) is also positive which means that an increment in ratings determines a rise in the annual average room price of the lodging establishment.

Furthermore, the estimated coefficients' signs in the GWR model concur with the OLS regression model. Additionally, the GWR's results exhibit a range of values (e.g. Landscape factor coefficients vary between -0.14605 and -0.141771 ) that are very close to the OLS factors' coefficients which are latent variables based on logarithms. Despite that fact, all three non-stationary variables in the GWR model suggest spatial variation in parameter values. These features will be commented bellow-throughout the spatial econometric analysis.

Spatial autocorrelation in the residuals of the OLS model was tested by measuring Moran's autocorrelation coefficient (Global Moran's I) of the residuals of $\operatorname{LnP}_{i}\left(x_{i}, y_{i}\right)$ (lodging establishment's annual average room price) using GeoDa (version 1.8.16.4; Anselin, 2017) software. The Moran's I index was tested statistically not significant at the $5 \%$ level. Thus, spatial autocorrelation in the annual average room price of accommodations in the Douro is not a prevalent issue as in other models, namely in urban areas

Table 5. Results—global and local models.

\begin{tabular}{|c|c|c|c|c|c|c|}
\hline & \multirow{3}{*}{$\begin{array}{l}\text { OLS model } \\
\text { Coeficcient }\end{array}$} & \multicolumn{4}{|c|}{ GWR_-mixed (semiparametric) model } & \multirow{3}{*}{$\begin{array}{c}\begin{array}{c}\text { Stationary } \\
\text { variables }\end{array} \\
\text { Coefficients }\end{array}$} \\
\hline & & \multicolumn{4}{|c|}{ Non-stationary variables } & \\
\hline & & $\begin{array}{l}\text { Lwr (25th) } \\
\text { quartile }\end{array}$ & Median & $\begin{array}{l}\text { Upr (75th) } \\
\text { quartile }\end{array}$ & Mean & \\
\hline Intercept term & $3.927783^{*}$ & 3.915279 & 3.916779 & 3.920807 & 3.921184 & \\
\hline Landscape factor (F1) & $-0.135921^{*}$ & -0.146053 & -0.145189 & -0.141771 & -0.141645 & \\
\hline Accessibility factor $(F 2)$ & $-0.091341^{*}$ & -0.100050 & -0.096424 & -0.091629 & -0.092346 & \\
\hline Site factor $(F 3)$ & $0.097532^{*}$ & 0.101768 & 0.101768 & 0.105523 & 0.100452 & \\
\hline Booking.com rating (BR) & $0.657059 *$ & & & & & 0.657059 \\
\hline$N_{2}$ & 130 & 130 & & & & \\
\hline$R^{2}$ & 0.37 & 0.39 & & & & \\
\hline$R^{2}$ [min.-max.] & - & {$[0.25-0.43]$} & & & & \\
\hline $\operatorname{Adj} R^{2}$ & 0.34 & 0.35 & & & & \\
\hline $\mathrm{AlC}_{\mathrm{c}}$ & 69.57024 & 69.26000 & & & & \\
\hline
\end{tabular}

*Statistically significant at $1 \%$ level. 
and sea resorts (Latinopoulos, 2018; Zhang et al., 2011), which could be due to the low density and more scattered distribution of accommodation units along the research area. Also, as noted by White and Mulligan (2002, p. 541) "spatial interdependence is possibly not as critical an issue" at a regional level "as it is at the intraurban scale".

Despite these results (Moran's I), the difference of estimates of the corrected Akaike Info Criterion $\left(\mathrm{AIC}_{\mathrm{C}}\right.$ ) between both models denotes a slight improvement on the goodness-offit of the local semiparametric GWR model, which exhibits a lower estimate $(-0.31)$, although the absolute result of the $\mathrm{AIC}_{\mathrm{c}}$ difference is below 1. Likewise, the semi-parametric GWR displays a higher $R^{2}(0.39)$ value, representative of a better model fit.

Summing up, regardless of the apparent absence of spatial autocorrelation of our global model the semi-parametric GWR provides local goodness-of-fit measures, namely $R^{2}$ estimates, which exhibit an extensive level of spatial dissimilarity, ranging from 0.25 to 0.43 . This broad interval, which includes values below the fixed $R^{2}$ estimate (0.37) of the global model, provides a new insight on the changing effects and magnitude produced by our model on the annual average room price which is far from spatially homogenous.

Based on the GWR's output we generated a spatially interpolated surface which illustrates the spatial variation of local $R^{2}$ values (Figure 3 ). This provides an overview that clearly depicts a horizontal change in the goodness-of-fit values along the study area and changing proportion of the variance on the dependent variable, with higher $R^{2}$ local estimates clustered on the western side where lodging establishments are more concentrated and denser and gradually decreasing towards the eastern section, which is sparsely occupied.

This visibly depicts a spatial pattern that outlines a distance decay effect which means that the interaction between two points decays as the distance between them increases, which our model seems to describe through a decreasing gradient of the level of proportion of the variance $\left(R^{2}\right)$ in the average annual room price (Figure 3 ) as the lodging establishments are more scattered.

The results confirm tourism's contingency on the Douro's landscape factors $(F 1)$, that combine dominant features such as the Douro river, the ADWR-UNESCO, the vineyards and the quintas. These attributes display a high level of significance of geographic variability across the hole study area (significance threshold at 98\%). Likewise, landscape parameter estimates exert higher influence on room prices of lodging establishment that are near these attributes and lesser influence over observations that are further away.

This pattern is validated by the spatially interpolated surfaces of the local $t$-statistics significance (Figure 4), which in the particular case of accessibility (F2) and site (F3) factors exhibit a decrease of the confidence level of the reliability of the estimation procedure as observations are more dispersed. Accordingly, the estimates' standard error follows the same spatial pattern.

Despite the prevalent rural and low-density morphology of the Douro region as well as some dispersion of lodging establishments that could elicit some concern with accessibility factors (F2), results display a decrease of the significance of parameter estimates as well as lower influence over lodging establishments that are more scattered.

Results show that distance to accessibility factors on more denser sections exhibit a significant negative effect on the annual average room prices which could mean that density increases competition and therefore accessibility features which make a given lodging establishment more convenient exert greater influence on the room price. 


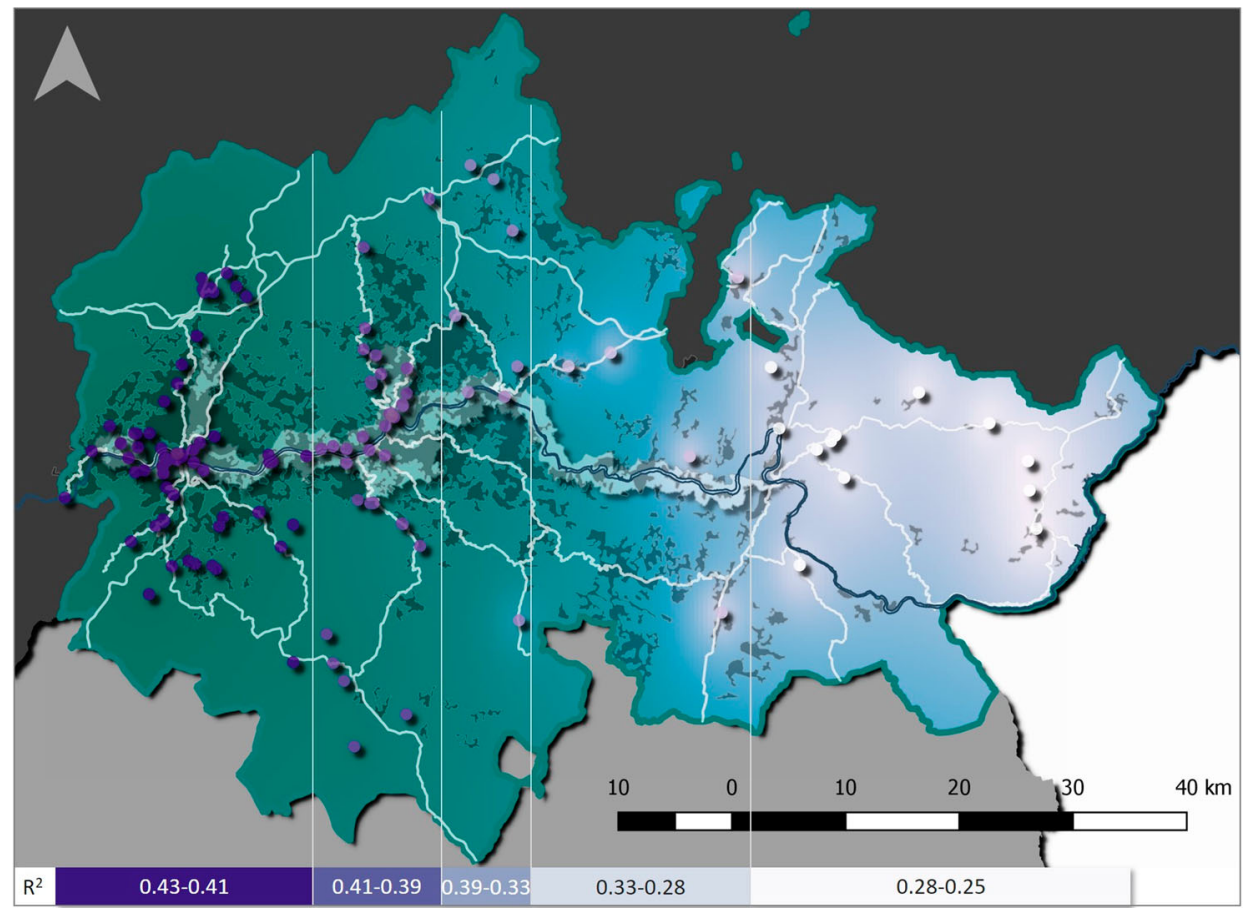

Figure 3. Spatial display of the local $R^{2}$ values.
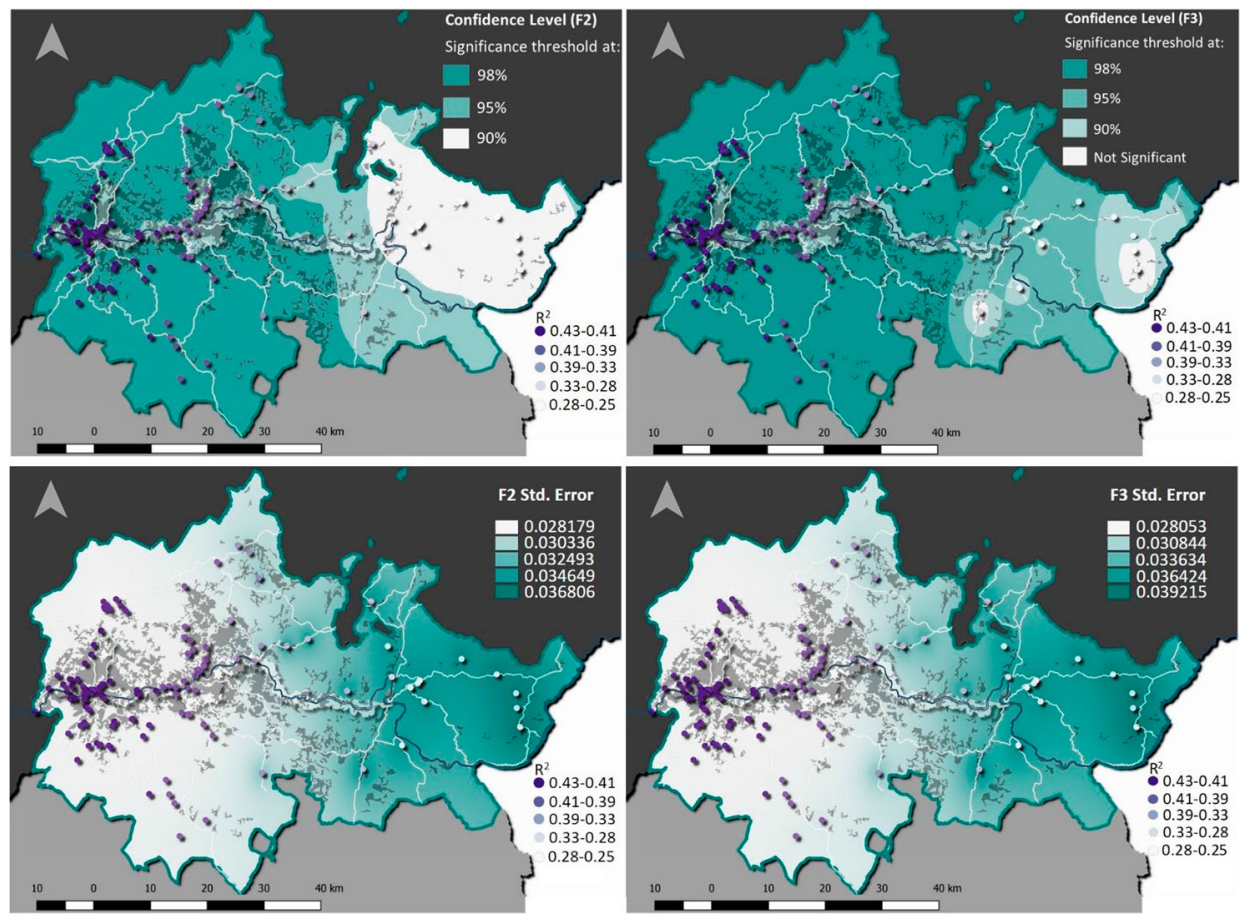

Figure 4. Spatial display of local $t$-statistics significance and standard errors of $F 2$ and $F 3$ factors. 
Furthermore, site factors (F3), which combine size and types of accommodations, decrease their significant effect on the variance of room prices where lodging establishments are more dispersed and in particular cases are not significantly associated with room price on our hedonic price model.

In addition, site factors (F3) exert a greater and positive influence on room price as size and level of sophistication (hotel versus hostels) increases (Figure 5). This factor has a stronger influence and more significant on the western side of our research area where lodging establishments are larger and more diverse, containing hotels, which are absent on the eastern section.

Regardless of the similarity with the OLS coefficients, the semi-parametric GWR's mean coefficients depict a variable and heterogenous spatial pattern where each factor influences the average annual room price unevenly along the study area. GWR captures the spatial change of the estimated coefficients' signs which concurs with the discussed theory, i.e. an increase in the lodging establishments distance to landscape and accessibility features tends to affect negatively room prices and an increase in the size and service sophistication of lodging tends to affect positively and raise room prices (Zhang et al., 2011).

Additionally, the way that prices change in respect to concentrated or dispersed spatial patterns of lodging establishments in the Douro region is clearly an empirical observation of Tobler's law (Tobler, 1970), which sanctions the assumption that lodging's room prices are also affected by their relative distance to each other and that near lodging establishments are more related than distant lodging establishments.

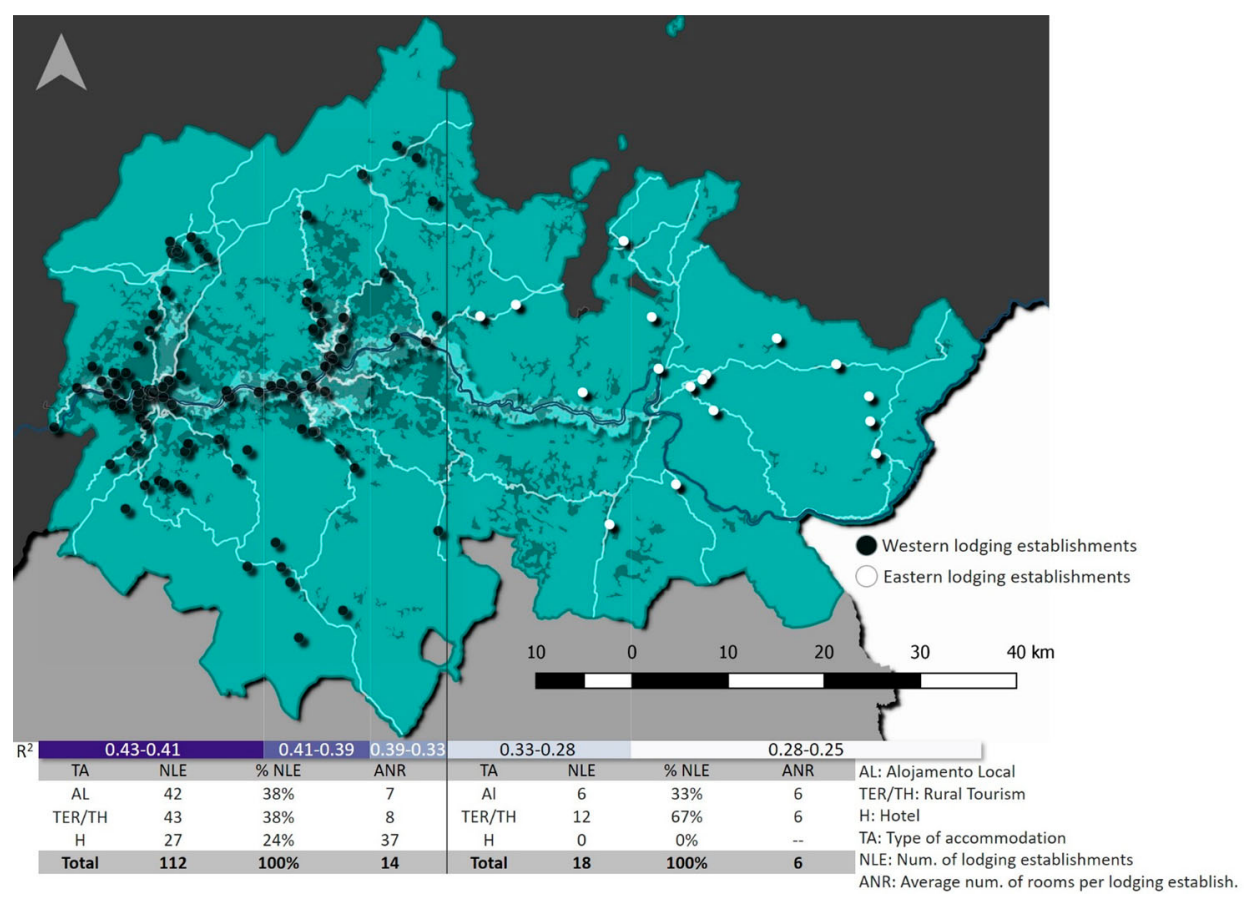

Figure 5. Influence of site factors (F3) on room price by geographical location. 


\section{Conclusions}

This article has contributed to gain a deeper knowledge of demand for agritourism and particularly for wine tourism by estimating the economic significance of the winescape's aesthetic value and its local economic effect on lodging establishments' room prices. To assess the aforesaid economic significance a semi-parametric GWR model was used which also combined site-specific and online reputation factors.

GWR analysis revealed a broad scale of local goodness-of-fit estimates (local $R^{2}$ values) which demonstrated relevant spatial dissimilarity. Therefore, the semi-parametric GWR model's results provided a fundamental overview of spatial variations of the annual average room price of lodging establishments located in a winescape environment, spatially dependent on factors that are concealed by the estimation of a global model and average measurement (OLS model). It thus provided a spatial context to construe a spatially variable phenomena as well as help decision making (Goodchild \& Janelle, 2004).

Our results confirm that lodging establishments' room price policies in a winescape environment are very much an outcome of the geographic context and spatially varying conditions, as well as dependent on the level of concentration of lodging establishments in space. Additionally, room prices and accommodation performance are also contingent on a global factor which provides online international reputation (Booking.com) based on the consumer's post-experience review. Thus, the semi-parametric GWR model supports both an interpretation of global factors' influence on room price as well as "spatial disaggregations of more familiar global statistics" (Fotheringham, 2009, p. 339).

The applied spatial hedonic model and study's findings offer a novel analytical overview on wine tourism's dynamics by providing evidence that wine tourism's development is susceptible to the winescape's aesthetic value induced by its core productive activity, the wine filière, and dependent on land use constraints such as UNESCO's classification. Results suggest that there is a selective impact of the winescape's aesthetic value on lodging room prices, which is demonstrated through the landscape's parameter estimates higher influence over lodging establishments that are near these features.

As a result, this research delivers practical managerial contributions by providing a framework that can be used to steer tourism planning in wine region destinations, namely by informing about the spatial varying aesthetic values of the winescape and further allowing to predict the effect on the winescape's touristic value of possible transformations in nature-related attributes.

So, this research provides economic evidence that makes it possible to argue in favor of the protection of the winescape's aesthetic value based on its touristic significance, which requires a systemic approach towards wine tourism destination planning and the need to establish a policy benchmark which articulates both wine and tourism development issues. Moreover, the spatial hedonic modeling gives an insight on prospective tourism development through room price valuation based on the winescape's aesthetic traits effect, i.e. it offers a critical tool to interpret density patterns in areas where the winescape has a significant and positive influence on room prices. This study also aids strategic managerial decisions concerning room pricing policy and marketing, by allowing a visual insight and understanding of the distance-decay effect which is dependent on the location and distance between lodging establishments as well as on fundamental factors such as the winescape's aesthetic value, the level of accessibility and site characteristics. 
Due to the predictive restrictions of cross-sectional data, this study does not capture the longitudinal transitions of the winescape's aesthetic impact on lodging room prices. Consequently, future research should use time-varying effect modeling to attain a seasonal breakdown view of this model and examine dynamic shifts of the winescape's aesthetic value.

\section{Acknowledgments}

The authors would like to thank the anonymous reviewers for their helpful and constructive comments that greatly contributed to improving the quality of this paper.

\section{Disclosure statement}

No potential conflict of interest was reported by the authors.

\section{Funding}

This work was supported by the project NORTE -01-0145-FEDER-000038 (INNOVINE \& WINE - Innovation Platform of Vine and Wine) and by European and Structural and Investment Funds in the FEDER component, through the Operational Competitiveness and Internationalization Programme (COMPETE 2020) [Project No 006971 (UIC/SOC/04011)]; and national funds, through the FCT - Portuguese Foundation for Science and Technology under the UID/SOC/04011/2013.

\section{ORCID}

Alexandre Guedes (1) http://orcid.org/0000-0003-2019-3535

João Rebelo (iD http://orcid.org/0000-0003-3564-7771

\section{References}

Abrate, G., Fraquelli, G., \& Viglia, G. (2012). Dynamic pricing strategies: Evidence from European hotels. International Journal of Hospitality Management, 31, 160-168.

Andersson, D. (2010). Hotel attributes and hedonic prices: An analysis of internet-based transactions in Singapore's market for hotel rooms. The Annals of Regional Science, 44, 229-240.

Andersson, H., \& Hoffmann, R. (2008). Spatial competition and farm tourism. A hedonic pricing model. In Proceedings of the 2008 Annual Meeting (pp. 27-29). Milwaukee, Wl: American Agricultural Economics Association.

Anselin, L. (2017). GeoDa [Computer software].

Bilbao-Terol, C., Cañal-Fernández, V., Valdés, L., \& Del Valle, E. (2017). Rural tourism accommodation prices by land use-based hedonic approach: First results from the case study of the self-catering cottages in Asturias. Sustainability, 9, 1-17.

Brunsdon, C., Fotheringham, A., \& Charlton, M. (1996). Geographically weighted regression: A method for exploring spatial nonstationarity. Geographical Analysis, 28(4), 281-298.

Bruwer, J. (2003). South African wine routes: Some perspectives on the wine tourism industry's structural dimensions and wine tourism product. Tourism Management, 24(4), 423-435.

Bruwer, J., \& Alant, K. (2009). The hedonic nature of wine tourism consumption: An experiential view. International Journal of Wine Business Research, 21(3), 235-257.

Bruwer, J., \& Gross, M. (2017). A multilayered macro approach to conceptualizing the winescape construct for wine tourism. Tourism Analysis, 22, 497-509.

Bruwer, J., Gross, M., \& Lee, H. (2016). Tourism destination image (TDI) perception within a regional winescape context. Tourism Analysis, 21, 173-187. 
Bruwer, J., \& Joy, A. (2017). Tourism destination image (TDI) perception of a Canadian regional winescape: A free-text macro approach. Tourism Recreation Research, 42(3), 367-379.

Bruwer, J., \& Lesschaeve, I. (2012). Wine tourists' destination region brand image perception and antecedents: Conceptualization of a winescape framework. Journal of Travel \& Tourism Marketing, 29(7), 611-628.

Bull, A. (1994). Pricing a motel's location. International Journal of Contemporary Hospitality Management, 6(6), 10-15.

Bull, A. (1998). The effects of location and other attributes on the price of products which are place-sensitive in demand (PhD., thesis). Griffith University.

Byrd, E., Canziani, B., Hsieh, J., Debbage, K., \& Sönmez, S. (2016). Wine tourism: Motivating visitors through core and supplementary services. Tourism Management, 52, 19-29.

Caldas, J., \& Rebelo, J. (2013). Portuguese wine ratings: An old product a new assessment. Wine Economics and Policy, 2, 102-110.

Carmichael, B. (2005). Understanding the wine tourism experience for winery visitors in the Niagara region, Ontario, Canada. Tourism Geographies, 7(2), 185-204.

Carvell, S., \& Herrin, W. (1990). Pricing in the hospitality industry: An implicit markets approach. FIU Hospitality Review, 8(2), 27-37.

Charlton, M., \& Fotheringham, A. (2009). Geographically weighted regression - white paper. Maynooth, Co Kildare: National Centre for Geocomputation, National University of Ireland. Retrieved from https://www.geos.ed.ac.uk/ gisteac/fspat/gwr/gwr_arcgis/GWR_WhitePaper.pdf

Chen, C., \& Rothschild, R. (2010). An application of hedonic pricing analysis to the case of hotel rooms in Taipei. Tourism Economics, 16(3), 1-10.

Costantino, G., Martinelli, F., \& Petrocchi, M. (2012). Priorities-based review computation. In Proceedings of the 2012 AAAl symposia: Intelligent web services meet social computing. Menlo Park, CA: AAAI. Retrieved from http://fileadmin.cs.Ith.se/ai/Proceedings/AAAI\%20SSS\%202012/ 01/SS12-04-007.pdf

Donnges, C. (2003). Improving access in rural areas: Guidelines for integrated rural accessibility planning. Bangkok: International Labour Office.

Espinet, J., Saez, M., Coenders, G., \& Fluvià, M. (2003). Effect on prices of the attributes of holiday hotels: A hedonic prices approach. Tourism Economics, 9(2), 165-177.

Fleischer, A. (2012). A room with a view - A valuation of the Mediterranean Sea view. Tourism Management, 33(3), 598-602.

Fleischer, A., \& Tchetchick, A. (2005). Does rural tourism benefit from agriculture? Tourism Management, 26, 493-501.

Fotheringham, A. (2009). "The problem of spatial autocorrelation" and local spatial statistics. Geographical Analysis, 41, 398-403.

Fotheringham, A., Brunsdon, C., \& Charlton, M. (2002). Geographically weighted regression: The analysis of spatially varying relationships. Chichester: John Wiley \& Sons.

Free Software Foundation, Inc. (2017). QGIS [Computer software].

Getz, D., \& Brown, G. (2006). Critical success factors for wine tourism regions: A demand analysis. Tourism Management, 27(1), 146-158.

Goodchild, M., \& Janelle, D. (2004). Thinking spatially in the social sciences. In M. Goodchild \& D. Janelle (Eds.), Spatially integrated social science (pp. 3-17). New York: Oxford University Press.

Gouveia, S., Rebelo, J., Lourenço-Gomes, L., \& Guedes, A. (2017). International demand for the Douro (Portugal) river cruises: A gravity model approach. Tourism Economics, 23(8), 1679-1686.

Guedes, A., \& Joukes, V. (2016). Hotel ships on the Douro River and their relationship with the terroir. In M. Peris-Ortiz, M. de la Cruz Del Río Rama, \& C. Rueda-Armengot (Eds.), Wine and tourism: A strategic segment for sustainable economic development (pp. 87-105). Cham: Springer International Publishing.

Hair Jr, J., Black, W., Babin, B., \& Anderson, R. (2014). Multivariate data analysis. Harlow: Pearson Education Limited.

Hall, C. M., \& Mitchell, R. (2002). The tourist terroir of New Zealand wine: The importance of region in wine tourism experience. In A. Montanari (Ed.), Food and environment: Geographies of taste (volume II) (pp. 69-91). Roma: Società Geografica Italiana. 
Hall, C. M., Sharples, L., Cambourne, B., \& Macionis, N. (2000). Wine tourism around the world. Jordan Hill: Butterworth-Heinemann.

Hamilton, J. (2007). Coastal landscape and the hedonic price of accommodation. Ecological Economics, 62, 594-602.

Hung, W., Shang, J., \& Wang, F. (2010). Pricing determinants in the hotel industry: Quantile regression analysis. International Journal of Hospitality Management, 29(3), 378-384.

Hunt, L., Boxall, P., Englin, J., \& Haider, W. (2005). Remote tourism and forest management: A spatial hedonic analysis. Ecological Economics, 53, 101-113.

INE (Statistics Portugal. (2016). Anuário Estatístico da Região Norte; III.11.5 - Dormidas nos estabelecimentos de alojamento turístico por município, segundo o continente de residência habitual, 2016. Retrieved from https://www.ine.pt/xportal/xmain?xpid=INE\&xpgid=ine_publicacoes\&PUBLICA COESpub_boui $=277187213 \&$ PUBLICACOEStema $=00 \&$ PUBLICACOESmodo $=2$

Israeli, A. (2002). Star rating and corporate affiliation: Their influence on room price and performance of hotels in Israel. International Journal of Hospitality Management, 21(3), 405-424.

Lancaster, K. (1966). A new approach to consumer theory. Journal of Political Economy, 74, 132-157.

Latinopoulos, D. (2018). Using a spatial hedonic analysis to evaluate the effect of sea view on hotel prices. Tourism Management, 65, 87-99.

Le Goffe, P. (2000). Hedonic pricing of agriculture and forestry externalities. Environmental and Resource Economics, 15, 397-401.

Li, B., Ghose, A., \& Ipeirotis, P. (2008, June). Stay elsewhere? Improving local search for hotels using econometric modeling and image classification. Paper presented at the 11 th International Workshop on Web and Databases (WebDB 2008), Vancouver.

Mellinas, J., María-Dolores, S., \& García, J. (2016). Effects of the Booking.com scoring system. Tourism Management, 57, 80-83.

Miossec, J. (1977). Un modèle de l'espace touristique. Espace géographique, 6(1), 41-48. Retrieved from http://www.persee.fr/doc/spgeo_0046-2497_1977_num_6_1_1690

Molina-Azorin, J., Pereira-Moliner, J., \& Claver-Cortés, J. (2010). The importance of the firm and destination effects to explain firm performance. Tourism Management, 31(1), 22-28.

Monty, B., \& Skidmore, M. (2003). Hedonic pricing and willingness to pay for bed and breakfast amenities in southeast Wisconsin. Journal of Travel Research, 42(2), 195-199.

Murdoch, J. (2006). Post-structuralist geography: A guide to relational space. London: SAGE.

Nakaya, T. (2015). Geographically weighted generalised linear modelling. In C. Brunsdon \& A. Singleton (Eds.), Geocomputation (pp. 200-220). London: SAGE.

Nakaya, T., Fotheringham, A., Charlton, M., \& Brunsdon, C. (2009). Semiparametric geographically weighted generalised linear modelling in GWR 4.0. In B. Lees \& S. Laffan (Eds.), 10th International Conference on GeoComputation. Sydney: UNSW. Retrieved from http://www. geocomputation.org/2009/PDF/Nakaya_et_al.pdf

Nelson, J. (2010). Valuing rural recreation amenities: Hedonic prices for vacation rental houses at deep Creek Lake, Maryland. Agricultural and Resource Economics Review, 39, 485-504.

Peña, A., Jamilena, D., Molina, M., \& Olmo, J. (2015). Rural lodging establishments: Effects of location and internal resources and characteristics on room rates. Tourism Geographies, 17(1), 91-111.

Peters, G. (1997). American winescapes: The cultural landscapes of America's wine country. Boulder, CO: Westview Press/Harpers Collins.

Poitras, L., \& Getz, D. (2006). Sustainable wine tourism: The host community perspective. Journal of Sustainable Tourism, 14(5), 425-448.

Quintal, V., Thomas, B., \& Phau, I. (2015). Incorporating the winescape into the theory of planned behaviour: Examining 'new world' wineries. Tourism Management, 46, 596-609.

Rebelo, J., Guedes, A., Gomes, L., \& Sequeira, M. (2013). Avaliação do Estado de Conservação do Bem Alto Douro Vinhateiro. Paisagem Cultural Evolutiva Viva - Paisagem Evolutiva e Viva. Vol. 2 - Estudos de Base (pp. 28-53). Porto: CCDRN/Estrutura de Missão do Douro, Universidade do Porto \& Universidade de Trás-os-Montes e Alto Douro.

Rosen, S. (1974). Hedonic prices and implicit markets: Product differentiation in pure competition. Journal of Political Economy, 82, 34-55. 
Santeramo, F., \& Barbieri, C. (2017). On the demand for agritourism: A cursory review of methodologies and practice. Tourism Planning \& Development, 14, 139-148.

Santeramo, F., Seccia, A., \& Nardone, G. (2017). The synergies of the Italian wine and tourism sectors. Wine Economics and Policy, 6, 71-74.

Similarweb. (2018). Booking.com: June 2018 overview. Retrieved from https://www.similarweb.com/ website/booking.com\#overview

Soler, I., \& Gemar, G. (2018). Hedonic price models with geographically weighted regression: An application to hospitality. Journal of Destination Marketing \& Management, 9, 126-137.

Suárez-Vega, R., Santana Jiménez, Y., \& Hernández Guerra, J. (2009). Valoración económica de las características espaciales de las casas rurales en Gran Canaria. Rect@ Actas, 17, 1-17.

Telfer, D. (2000). The Northeast wine route: Wine tourism in Ontario, Canada and New York state. In C. Hall, L. Sharples, B. Cambourne, \& N. Macionis (Eds.), Wine tourism around the world (pp. 253-271). Jordan Hill: Butterworth-Heinemann.

Thrane, C. (2007). Examining the determinants of room rates for hotels in capital cities: The Oslo experience. Journal of Revenue and Pricing Management, 5(4), 315-323.

Tobler, W. (1970). A computer movie simulating urban growth in the Detroit region. Economic Geography, 46, 234-240.

Vanslembrouck, I., Van Huylenbroek, G., \& Van Mennesel, J. (2005). Impact of agriculture on rural tourism: A hedonic pricing approach. Journal of Agricultural Economics, 56, 17-30.

Viers, J., Williams, J., Nicholas, K., Barbosa, O., Kotze, I., Spence, L., ... Reynolds, M. (2013). Vinecology: Pairing wine with nature. Conservation Letters, 6(5), 287-299.

White, P., \& Mulligan, G. (2002). Hedonic estimates of lodging rates in the four corners region. The Professional Geographer, 54(4), 533-543.

Williams, P. (2001). The evolving images of wine tourism destinations. Tourism Recreation Research, 26(2), 3-10.

Wooldridge, J. (2009). Introductory econometrics: A modern approach. Mason: South Western Cengage Learning.

$\mathrm{Wu}$, L. (1999). The pricing of a brand name product franchising in the motel services industry. Journal of Business Venturing, 14(1), 87-102.

Yacouel, N., \& Fleischer, A. (2012). The role of cybermediaries in reputation building and price premiums in the online hotel market. Journal of Travel Research, 51(2), 219-226.

Yang, Z., \& Cai, J. (2016). Do regional factors matter? Determinants of hotel industry performance in China. Tourism Management, 52, 242-253.

Zhang, H., Zhang, J., Lu, S., Cheng, S., \& Zhang, J. (2011). Modeling hotel room price with geographically weighted regression. International Journal of Hospitality Management, 30, 1036-1043. 